CASE REPORT

\title{
Multiple Cutaneous Melanomas
}

\author{
Carmen Cristina DRAGHICl${ }^{1}$, Adelina POPA ${ }^{1}$, Florica SANDRU ${ }^{1,2}$
}

\begin{abstract}
Cutaneous melanoma is a malignant tumor that develops from melanocytes found in the basal layer of the epidermis. Even though it is not the most common type of skin cancer, it is the most aggressive one with an increasing incidence worldwide. The risk factors inherited in the appearance of melanoma are sun exposure together with severe sunburns in childhood and adolescence, high number of moles and genetic factors. We present the case of a 66 years old women with numerous skin sunburns in the past years who refer to our clinic for three pigmented skin lesions, with asymmetrical edges, elevated to the cutaneous plane, with a diameter of $2 \mathrm{~cm}$ for the largest one and chromatic dysmorphism, located on the posterior thorax. The dermoscopic examination was suggestive for cutaneous melanoma. We performed the surgical excision of all three cutaneous tumors and the histopathologic examination was performed. The diagnosis of all three lesions was of melanoma. A CT examination was made together with sentinel node biopsy. The aim of this paper is to present a rare case of simultaneous three skin melanomas and the treatment alternatives of this patient after clinical and paraclinical investigations.
\end{abstract}

Keywords: melanoma, sentinel node, skin sunburns.

\section{Rezumat}

Melanomul cutanat este o tumoare malignă ce se dezvoltă din melanocitele din stratul bazal al epidermului. Chiar dacă nu este cel mai frecvent tip de cancer de piele, acesta este cel mai agresiv, cu o incidență în creștere la nivel mondial. Factorii de risc implicați în apariția melanomului sunt expunerea la soare, împreună cu arsurile solare severe în copilărie și adolescență, numărul mare de nevi și factorii genetici. Vă prezentăm cazul unei femei în vârstă de 66 ani, cu numeroase arsuri solare cutanate în ultimii ani, care se prezintă în cadrul clinicii noastre pentru trei leziuni cutanate pigmentate, cu margini asimetrice, cu un diametru de $2 \mathrm{~cm}$ pentru cea mai mare și avand dismorfism cromatic, situate pe toracele posterior. Examenul dermoscopic a fost sugestiv pentru diagnosticul de melanom cutanat. Am efectuat excizia chirurgicală a tuturor celor trei tumori cutanate impreună cu examenul histopatologic. Diagnosticul celor trei leziuni a fost de melanom. O examinare CT a fost făcută împreună cu biopsia ganglionului santinelă. Scopul acestei lucrări este de a prezenta un caz rar de trei melanoame simultane ale pielii și alternativele de tratament ale acestui pacient după investigații clinice și paraclinice.

Cuvinte cheie: melanom, ganglion santinela, arsuri solare.

\footnotetext{
1 Department of Dermatology, „Elias" University Emergency Hospital, Bucharest, Romania

2 "Carol Davila" University of Medicine and Pharmacy, Bucharest, Romania
}

Corresponding author. Adelina POPA, Department of Dermatology, „Elias" University Emergency Hospital, 17 Marasti Boulevard, $1^{\text {st }}$ District, Bucharest, Romania.

E-mail: adelinaade541@yahoo.com 


\section{INTRODUCTION}

Cutaneous melanoma is one of the most common cancers worldwide, with the highest growth rate among the world population compared to other neoplasms ${ }^{1}$. The incidence of melanoma varies depending on the cutaneous fototype, the level of exposure to ultraviolet radiation and the geographic region. Moreover, unlike other neoplasms, cutaneous melanoma generally affects young adults, with the average of 57 years old, having a progressive growth rate with age. Also, the incidence grows among young women but also among middleaged men $^{2}$.

Regarding environmental risk factors, ultraviolet light radiation, especially UVB spectrum, is mainly associated with melanoma. Additionally, intense or intermittent exposure to sun lights together with sunburns during childhood or adolescence are described as risk factors for developing melanoma $a^{3-5}$. Also, there are studies that associate melanoma and the amound of sunbed usage compared with other environmental risk factor such as smoking that are not related with melanoma develpoment1. Another important factors that increases the susceptibility to develop melanoma is the number of congenital and aquired melanocytic nevi together with family history of melanoma due to the fact that $25 \%$ of cutaneous melanoma develop on an pre-existing nevus ${ }^{6}$. All these data suggests that the increased number of nevi but also their size and type are important risk factors for melanoma ${ }^{7-9}$.

\section{MATERIAL AND METHODS}

We present the case of a 66 years old women who reffered to Dermatology Clinic of Elias Universitary Emergency Hospital for a clinical evaluation of the body nevi, especially for three pigmented lesions that she cosidered that had changed their size and aspect in the last few months. Her personal history included frequent sun exposure and numerous skin burns during her life. She addmited not using sunscreen in her daily life and also during sun exposure. No other pathologies were associated. Her family history was clear of any segnificant diseases.

Clinical examination revelead numerous cutaneous nevi and solar lentigines together with three pigmented lessions localized on her posterior thorax. Their size varies from $2 \mathrm{~cm}$ to $1 \mathrm{~cm}$ with irregular contour but also chromatic and structural dysmorphism.

Dermoscopic examination was performed revealing three asymmetric lesions with atypical pigmented network composed of black, browns and grey network

Figure 1. Pigmented lesions located on the posterior thorax.

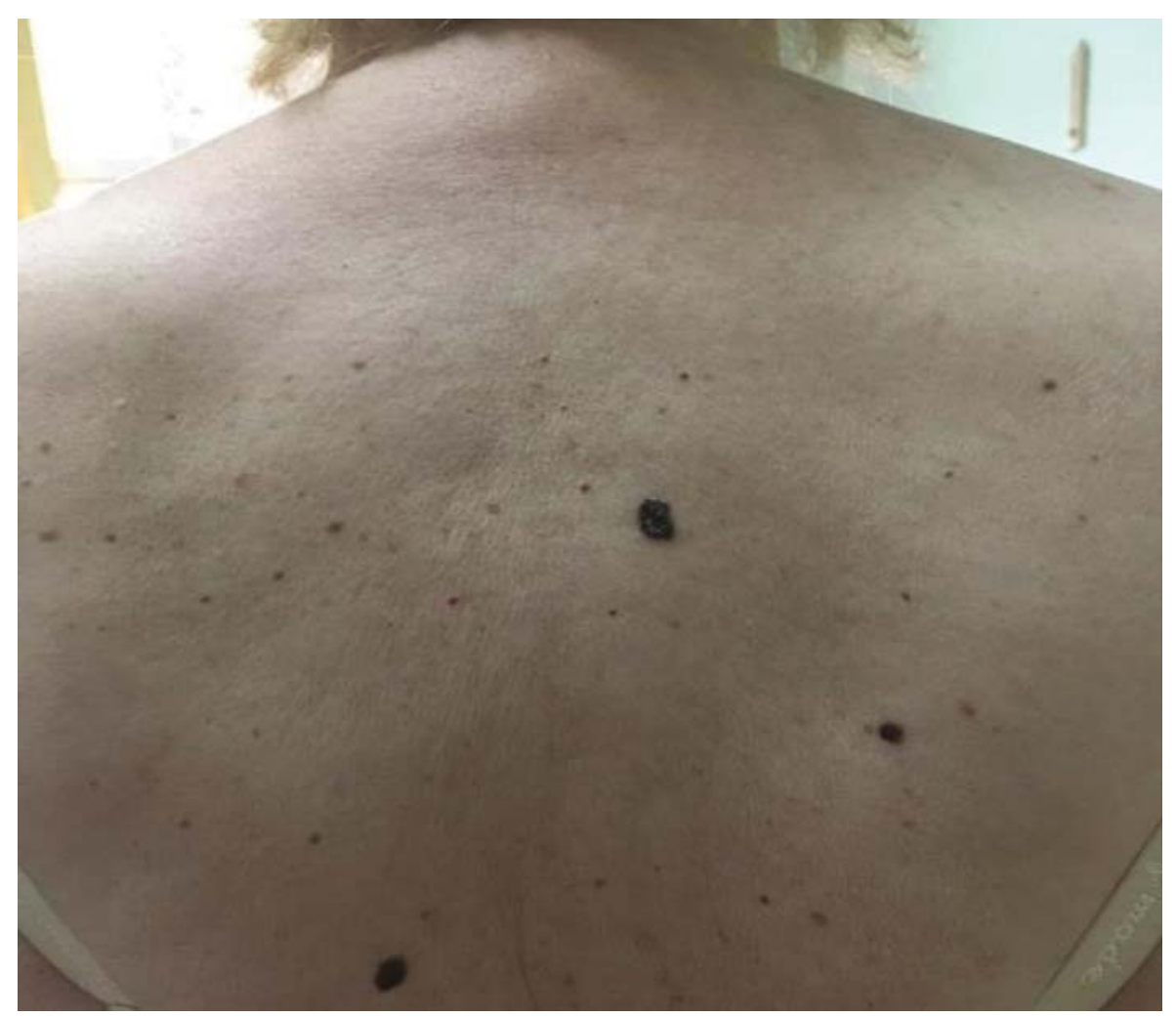




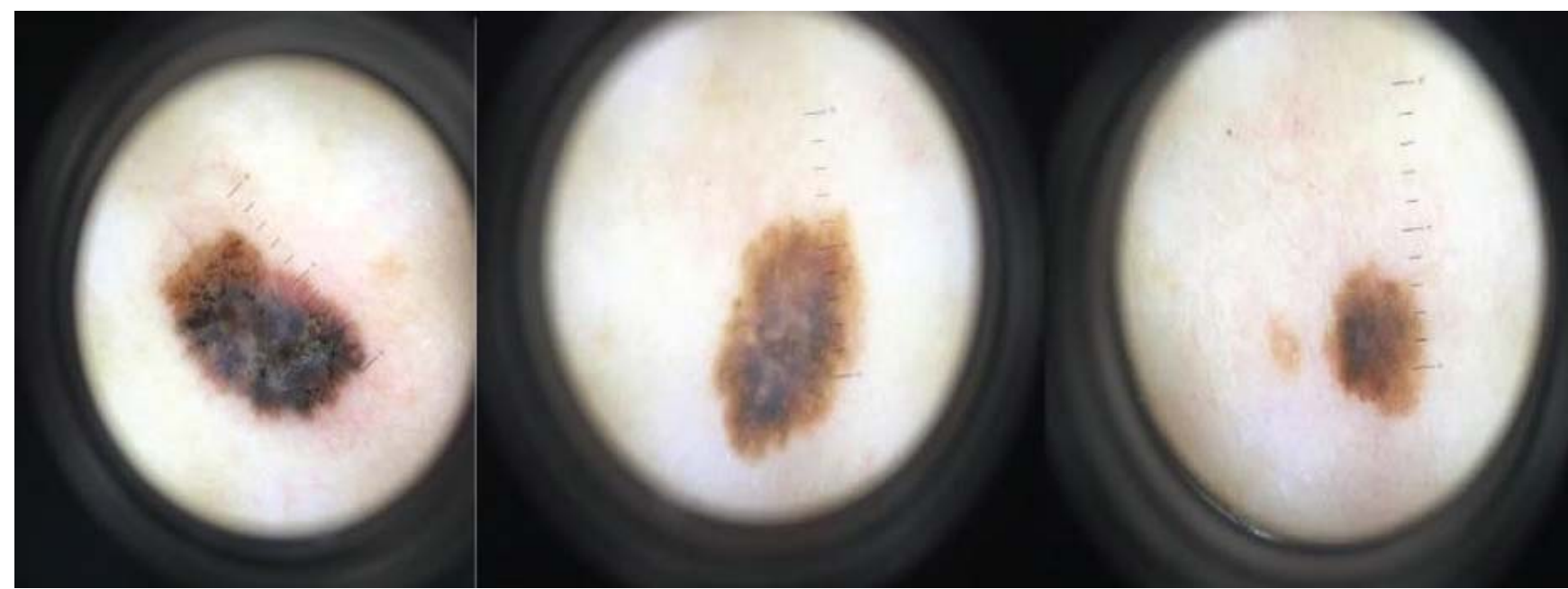

Figure 2. Dermoscopic view of the pigmented lesions.

with irregular holes and lines, with blue-white veil that correspond to a clinically elevated part seen in the biggest lesion, with pigmented lines angulated one to the other tending to form polygonal geometrical shapes, irrelular blotches and globules (black and brown oval or round structures of different size distributed within the lesion). Radial streaming, radial streaks and pseudopods were seend in periphery that indicates malignancy. The vascular pattern was also atypical with linear irregular vessels together with polymorphous vascular dotted vessels.

The surgical excision of all three cutaneous tumors was performed together with the histopathologic examination which revealed the diagnosis of superficial spreading melanoma with 1.2 Breslow index, Clark stage IV for the first one, superficial spreading melanoma with 0.8 Breslow index, Clark stage III for the second one and superficial spreading melanoma with 0.45 Breslow index, Clark stage III for the third one.

We performed the santinel node biopsy in order to determine if melanoma had spread beyond the primary tumor into any lymphatic areas. The surgical procedure involves injecting a tracer material that helps the surgeon to locate the santinel nodes involved in the tumour drainage. The histopathologic exam of the lymph node was negative. The PET- CT. examination described no metabolic active lesions.

\section{RESULTS AND DISCUSSIONS}

We decided together with the oncologist to monitor the patient both through repeated dermatologically examination at certain intervals but also through lymph node ultrasound and laboratory tests. The follow-up revelead any metastatic tumour, but one year later, at routine dermatologically control, a superficial tumor formation was revealed.

The clinical examination showed a flat, scaly, reddish patch with $1 \mathrm{~cm}$ diameter with tiny blood vessels in surface located also on posterior thorax. The dermoscopic exam described an asymmetric lesion with leaflike areas, shiny white blotches and strands, arborizing branched vessels suggesting a basal cell carcinoma. Surgical excision of tumor was practiced, and histopathological examination confirmed the diagnosis of basal cell carcinoma.

The patient is still under dermatological and oncological periodic monitoring.

\section{CONCLUSION}

Melanoma has the fastest increase in incidence for any cancer. The cure rate is closely related to disease stage, suggesting that ealy detection and referral to a specialist for diagnosis and treatment are essential to improving outcomes. Therefore, education aboud risk factors and period examination of nevi are recommended.

This case is differentiated from the other presented by the particularity of having three concomitant melanomas. They were in different phases of evolution, the largest one already had potential for metastasis. This case shows that the primary detection of melanoma, in the incipient phase, is essential in decreasing the risk of developing metastases and increasing the survival rate in this type of cancer. 
Compliance with ethics requirements: The authors declare no conflict of interest regarding this article. The authors declare that all the procedures and experiments of this study respect the ethical standards in the Hel-

\section{References}

1. Ali Z, Yousaf N, Larkin J. Melanoma epidemiology, biology and prognosis. EJC Suppl. 2013;11:81-91. doi: 10.1016/j.ejcsup.2013.07.012. [PMC free article] [PubMed] [CrossRef] [Google Scholar]

2. Rastrelli M, Tropea S, Rossi CR, Alaibac M. Melanoma: Epidemiology, risk factors, pathogenesis, diagnosis and classification. In Vivo. 2014;28:1005-1011. [PubMed] [Google Scholar]

3. Leonardi G.C., Falzone L., Salemi R. Cutabeous melanoma: from pathogenesis to therapy (review), Int J Oncol 2018, 52(4):10711080

4. Pennello G, Devesa S, Gail M. Association of surface ultraviolet $B$ radiation levels with melanoma and nonmelanoma skin cancer in United States blacks. Cancer Epidemiol Biomarkers Prev. 2000;9:291-297. [PubMed] [Google Scholar]

5. Falzone L, Marconi A, Loreto C, Franco S, Spandidos DA, Libra M. Occupational exposure to carcinogens: Benzene, pesticides and fibers (Review) Mol Med Rep. 2016;14:4467-4474. doi: 10.3892/mmr.2016.5791. [PMC free article] [PubMed] [CrossRef] [Google Scholar]

6. Bevona C, Goggins W, Quinn T, Fullerton J, Tsao H. Cutaneous melanomas associated with nevi. Arch Dermatol. 2003;139:16201624. doi: 10.1001/archderm.139.12.1620. discussion 1624. [PubMed] [CrossRef] [Google Scholar] sinki Declaration of 1975, as revised in 2008(5), as well as the national law. Informed consent was obtained from all the patients included in the study.

7. Seykora J, Elder D. Dysplastic nevi and other risk markers for melanoma. Semin Oncol. 1996;23:682-687. [PubMed] [Google Scholar]

8. Watt AJ, Kotsis SV, Chung KC. Risk of melanoma arising in large congenital melanocytic nevi: A systematic review. Plast Reconstr Surg. 2004;113:1968-1974. doi: 10.1097/01. PRS.0000122209.10277.2A. [PubMed] [CrossRef] [Google Scholar]

9. Gandini S, Sera F, Cattaruzza MS, Pasquini P, Abeni D, Boyle P Melchi CF. Meta-analysis of risk factors for cutaneous melanoma: I. Common and atypical naevi. Eur J Cancer. 2005;41:2844. doi: 10.1016/j.ejca.2004.10.015. [PubMed] [CrossRef] [Google Scholar

10. Rigel D. Cutaneous ultraviolet exposure and its relationship to the development of skin cancer. J Am Acad Dermatol. 2008, 58((5 suppl 2)):S129-S132

11. Naeyaert J. M., Brochez L. Dysplastic nevi. N Engl J Med. 2003 349((23)):2233-2240

12. Jhappan C., Noonan F. P., Merlino G. Ultraviolet radiation and cutaneous malignant melanoma. Oncogene. 2003;22:30993112. 